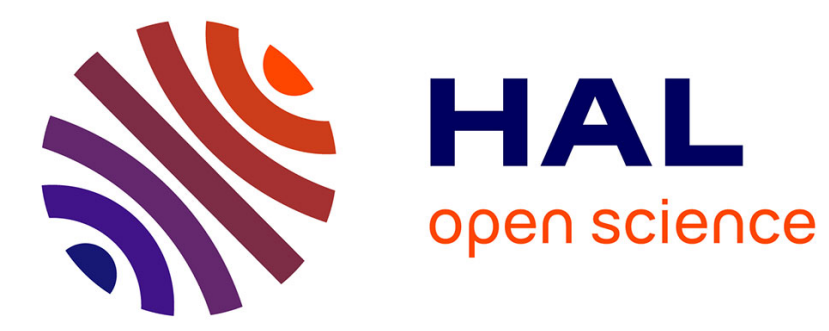

\title{
Endocranial anatomy of plesiosaurians (Reptilia, Plesiosauria) from the Late Cretaceous (Turonian) of Goulmima (Southern Morocco)
}

Rémi Allemand, Alexandra Houssaye, Nathalie Bardet, Peggy Vincent

\section{To cite this version:}

Rémi Allemand, Alexandra Houssaye, Nathalie Bardet, Peggy Vincent. Endocranial anatomy of plesiosaurians (Reptilia, Plesiosauria) from the Late Cretaceous (Turonian) of Goulmima (Southern Morocco). Journal of Vertebrate Paleontology, 2019, 39 (2), pp.e1595636. 10.1080/02724634.2019.1595636 . hal-02354078

\section{HAL Id: hal-02354078 \\ https://hal.science/hal-02354078}

Submitted on 7 Nov 2019

HAL is a multi-disciplinary open access archive for the deposit and dissemination of scientific research documents, whether they are published or not. The documents may come from teaching and research institutions in France or abroad, or from public or private research centers.
L'archive ouverte pluridisciplinaire HAL, est destinée au dépôt et à la diffusion de documents scientifiques de niveau recherche, publiés ou non, émanant des établissements d'enseignement et de recherche français ou étrangers, des laboratoires publics ou privés. 
Endocranial anatomy of plesiosaurians (Reptilia, Plesiosauria) from the Late Cretaceous (Turonian) of Goulmima (Southern Morocco)

RÉMI ALLEMAND, ${ }^{*}{ }^{1,2}$ ALEXANDRA HOUSSAYE, ${ }^{2}$ NATHALIE BARDET, ${ }^{1}$ and

\section{PEGGY VINCENT ${ }^{1}$}

${ }^{1}$ Centre de Recherches sur la Paléobiodiversité et les Paléoenvironnements, CR2P - UMR 7207 - CNRS - UPMC - Muséum National d'Histoire Naturelle, Sorbonne Université, 57 rue Cuvier, CP38, F-75005, Paris, France, remi.allemand@edu.mnhn.fr, nathalie.bardet@mnhn.fr, peggy.vincent@mnhn.fr; ${ }^{2}$ Mécanismes Adaptatifs et Evolution, MECADEV - UMR 7179 - CNRS - Muséum National d'Histoire Naturelle, Sorbonne Université, 55 rue Cuvier, CP55, F-75005, Paris, France, alexandra.houssaye@mnhn.fr RH: ALLEMAND ET AL. —ENDOCRANIAL ANATOMY OF PLESIOSAURIANS

.

5

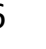

17

18

9


ABSTRACT - Despite recent advances in non-invasive imaging, Plesiosauria remains one of the least explored clade of reptiles with respect to palaeoneuroanatomy. Only partial endocasts, obtained from either latex casts or imprints left on the braincase, have been described so far. In this contribution, the digital endocasts of three plesiosaurian specimens were analysed: two referred to the Elasmosauridae Libonectes morgani and one undetermined Polycotylidae, all from the Late Cretaceous (Turonian) of Goulmima (Morocco). They were CT-scan generated in order to provide new anatomical information on the plesiosaurian endocast, endosseous labyrinth and cranial nerves. Results show that the three endocasts are very similar to each other. They appear anteroposteriorly elongated and horizontally oriented in lateral view, with long olfactory tracts, relatively small and incomplete olfactory bulbs, a reduced pineal organ, distinguishable optic lobes, and a possible large cerebellum constituting the main component in size of the endocast. The endocranial features reconstructed here are compared to those of other plesiosaurians, as well as other marine reptiles, notably to discuss their intraspecific and interspecific variability. This study provides pioneer data in order to estimate the impact of both phylogenetical and ecological constraints on the endocranial morphology of plesiosaurians and proposes a few preliminary paleobiological suggestions.

\section{INTRODUCTION} ranging groups of Mesozoic marine reptiles, extending stratigraphically from the Late Triassic to the latest Cretaceous (e.g., Vincent et al., 2011; Benson et al., 2012; Bardet et al., 2014). By the earliest Jurassic, they were an important component of the marine ecosystem (e.g., Sennikov and Arkhangelsky, 2010). Plesiosaurians possess an unusual body plan with a short and stiff trunk, a short tail and four enlarged hydrofoil-shaped propulsive flippers for 
swimming (e.g., Bardet et al., 2014). The proportions between head size and neck length result in a gradation in body form between "plesiosauromorph" (long neck, small head) and "pliosauromorph" (short neck, large head) morphotypes, which occurred independently in multiple phylogenetic lineages (e.g., Benson et al., 2012). Their degree of adaptation to the aquatic realm have been extensively studied based on skeletal (e.g., Caldwell, 1997; O’Keefe, 2002; Araújo et al., 2014), micro-anatomical and histological (e.g., Wintrich et al., 2017), as well as physiological (i.e., diet, reproduction, thermoregulation; Massare, 1987, 1988; Bernard et al., 2010; O'Keefe and Chiappe, 2011) features. Different lifestyles, as well as different ecological niches and feeding guilds have been inferred from their diverse morphologies and locomotor abilities (e.g., O’Keefe, 2002; Bardet et al., 2014). Most plesiosaurians are presumably piscivorous (e.g., Tarlo, 1959; Massare, 1987; Storrs, 1995; Sato and Tanabe, 1998). However, tooth marks on isolated bones indicated that some large pliosauromorphs preyed upon other reptiles (Clark and Etches, 1992) and that some plesiosauromorphs were specialized predators of invertebrates dwelling on marine sediments (e.g., McHenry et al., 2005; O'Keefe et al., 2017; Vincent et al., 2017). In addition, several studies suggested that all plesiosaurians were viviparous taxa with a K-selected reproduction strategy suggesting social behaviour and maternal care (O'Keefe and Chiappe, 2011; Wintrich et al., 2017), able to regulate their body temperature independently from the surrounding water temperature (Bernard et al., 2010), capable of performing deep, prolonged, and/or repetitive dives (Rothschild and Storrs, 2003), and to migrate, at least occasionally, over long distances (Vincent et al., 2017).

Although recent advances in non-invasive imaging have increased the number of taxa for which the endocranial morphology is accessible (e.g., Paulina-Carabajal et al., 2013; Cuthbertson et al., 2015; Kishida et al., 2015; Marek et al., 2015; Voeten et al., 2018), only the plesiosaurian endosseous labyrinth has been so far analysed (e.g., Neenan et al., 2017), 
and the current understanding of their neuroanatomy remains poor. Partial endocasts are known for Brancasaurus brancai (Edinger, 1928 see Hopson, 1979), Libonectes morgani (Carpenter, 1997) and Terminonatator ponteixensis (Sato, 2003). The endocast of

Brancasaurus is a wax cast modelled based on isolated cranial elements (Hopson, 1979;

Sachs et al., 2016). Edinger (1928) illustrated the cast but did not provide an associated description that shows little useful detail (Hopson, 1979), only the posterior part of the endocast, the inner cavity, and the pituitary fossa being indicated (Sachs et al., 2016). The endocast of Libonectes was taken from a latex cast of the braincase (Carpenter, 1997). The partial endocast is more detailed than that of Brancasaurus and Carpenter (1997) gave a brief description of the structure. Finally, Sato (2003) provided a short description of the dorsal endocranial surface in $T$. ponteixensis based on prints left on the ventral surface of the braincase roof.

Here, the use of microtomography on three plesiosaurian specimens from the

Goulmima area, Southern Morocco, offers access to endocranial structures that are described in detail. These new data are a first step to better interpret the endocranial morphology of plesiosaurians in general.

Institutional Abbreviations_-D, Musée de Paléopolis, Gannat, France; MNHN, Muséum National d'Histoire Naturelle, Paris, France; SMNS, Staatliches Museum für Naturkunde, Stuttgart, Germany; SMU SMP, Shuler Museum of Paleontology, Southern Methodist University, Dallas, U.S.A.

\section{MATERIAL AND METHODS}

The three specimens analysed come from the Goulmima area, Er-Rachidia Province in Southern Morocco. Stratigraphically, they come from the Unit T2a of the Akrabou Formation 
defined by Ettachfini and Andreu (2004) and lower Turonian in age (Kennedy et al., 2008; see Fig. 1 in Allemand et al., 2017a for the paleogeographical location and the stratigraphical range). As often in the Goulmima area, very well preserved zones alternate with others in which the bones are dissolved so that only their imprints are preserved. The fossils are embedded in nodules so that they present the advantage to be preserved in three dimensions and to be relatively undistorted (Fig. 1).

The three specimens were scanned at the AST-RX platform of the MNHN (Paris, France) using a GEphoenix|Xray|v|tome|x L240. The virtual three-dimensional reconstruction of the skulls was performed for the specimen descriptions and taxonomic assignment (Allemand et al., 2017a, 2018). The specimens SMNS 81783 and D1-8213 are referred to the elasmosaurid Libonectes morgani (Allemand et al., 2017a, 2018) and MNHN F-GOU14 to an undetermined polycotylid (Allemand et al., 2018). For this study, virtual three-dimensional reconstructions of the brain endocasts, cranial nerves and endosseous labyrinths were performed at the Palaeontology Imaging Unit of the UMR 7207 CR2P CNRS/MNHN/UPMC using the MIMICS (Materialise Interactive Medical Image Control System) Innovation Suite software (Materialise®, release 19).

The endocranial cavity of each specimen beeing filled with matrix, reconstructions were performed manually with the multiple 2D cross-sectional slices edit tool of MIMICS and interpolation between selections on non-contiguous slices. The isolation of the endocranial cavity was performed based on contrast differences between the bones, with darker grayscale values, and the matrix (Fig. 2 and Appendix 1). The posterior part of the brain endocast was delimited from the surrounding supraoccipital (dorsally; Fig. 2G, H), by the prootics and the exoccipital-opisthotic (laterally; Fig. 2G-I), by the basioccipital and the parabasisphenoid (ventrally; Fig. 2G-I) based on these contrast-differences. However, since the ventral and lateral walls of the anterior portion of the braincase are not ossified in plesiosaurians 
(O'Keefe 2001), accurate reconstruction of the anterior part of the endocast was not possible through segmentation (Fig. 2C-E).

\section{DESCRIPTION OF THE ENDOCRANIAL ANATOMY}

The cranial endocast of D1-8213 was almost completely reconstructed, together with the cranial nerves and the endosseous labyrinth (Fig. 3A). Only the olfactory bulbs were not reconstructed due to state of preservation. The dorsal surface of the brain cast in SMNS 81783 was reconstructed from the olfactory bulbs to the cerebellum, as well as few cranial nerves; however, the poor contrast-differences prevented the reconstruction of the endosseous labyrinth (Fig. 3B). The brain cast of MNHN F-GOU14 is the less complete and the more crushed one (Fig. 3C). Only its dorsal surface could be partially reconstructed; and both the anteriormost and posteriormost parts, as well as endosseous labyrinth and cranial nerves, are missing due to state of preservation.

\section{Brain Endocast}

Although the endocast is rarely a representation of the brain itself (Hurlburt et al., 2013), we use the brain anatomical nomenclature to describe the different structures of the plesiosaurian endocasts.

The endocranial morphology of the three plesiosaurian specimens is globally similar. Brain casts are elongated and mediolaterally narrow. The three specimens exhibit a slight ventral flexure at the level of the contact between the olfactory tracts and the cerebrum (Fig. 3A-C). The most anterior part of the brain cast corresponds to the olfactory bulbs. They have been reconstructed only in SMNS 81783 (Fig. 3B), in which the ventral surface of the dorsomedian ridge of the premaxilla and the anterior part of the frontal show their 
impressions. Despite a partial reconstruction that does not allow to observe their ventral surface, the olfactory bulbs appear wider than the olfactory tracts (Fig. 3B). The later are projected through the ventral wall of the frontal and appear elongated. The olfactory tracts become more mediolaterally compressed at their mid-length, and widen at the contact with the cerebrum (Fig. 3B). The anteroposterior length of the olfactory tracts is approximately 76 $\mathrm{mm}$ in SMNS 81783, which corresponds to about half of the length of the brain cast. No separation is visible between the olfactory tracts (Fig. 3A-C). The cast of the tracts continues posteriorly until they meet the cast of the cerebrum, visible on the ventral surface of the parietal. The cerebrum extends anteroposteriorly; however, due to the open condition of the braincase, its lateral and ventral extensions are not preserved. The dorsal surface of the cerebrum appears dorsoventrally concave just posterior to the contact with the olfactory tracts. The concavity is more strongly marked in both Libonectes morgani specimens (Fig. 3A-B) than in the undetermined polycotylid (Fig. 3C), and appears more extended antero-posteriorly in D1-8213 than in SMNS 81783. Posteriorly to the concavity observed on the dorsal surface of the cerebrum, a small bulge may correspond to the pineal organ (Fig. 3A-C). Its position in the mid-section of the parietals coincides with the foramen within the parietals in the undetermined polycotylid MNHN F-GOU14 (Allemand et al., 2018) but not with the pineal foramen located more anteriorly at the level of the postorbital bar in the L. morgani specimen SMNS 81783 (Allemand et al., 2017a). Posteriorly to the possible pineal organ, a more pronounced bulge on the dorsal surface of the brain cast indicates the position of the optic lobes (Fig. 3A-C), which are enclosed dorsally by the parietal. Ventrally to the optic lobes, the pituitary bulb is projected more ventrally than the ventral surface of the posterior part of the brain cast (Fig. 3A-B). Its ventral surface is horizontal and a pair of internal carotid foramen is visible at the posterior end of the pituitary bulb. The posterior part of the brain cast, the rhombencephalon, consists of the cerebellum and the medulla oblongata (Fig. 3A-B). The 
cerebellum is incomplete in SMNS 81783 and MNHN F-GOU14 but, in the three specimens it forms an anteroposteriorly developed bulge on the dorsal surface of the endocast (Fig. 3AB). Its dorsal surface slopes posterodorsally and constitutes the main structure of the plesiosaurian brain cast. The medulla oblongata, more complete in D1-8213 is thin and laterally constricted (Fig. 3A), enclosed by the prootics and the exoccipitals. Ventrally, the surface can be reconstructed with reasonable accuracy, as it is framed by the dorsal surfaces of the basisphenoid and basioccipital.

\section{Cranial Nerves}

Following the descriptions made on plesiosaurian braincases (e.g., Sato et al., 2011; Sachs et al., 2015), it is possible to identify the trigeminal nerve (V) as it corresponds to the prootic fenestra (Carpenter, 1997) but not its extension (Fig. 3A). The abducens nerve (VI) is anteriorly projected through the dorsolateral foramen of the pituitary fossa (Fig. 3A-B and Fig. 4A). The canal for the facial nerve (VII) exits from the foramen on the prootic, posteriorly to the abducens nerve and just anterior to the endosseous labyrinth (Fig. 3A and 4A). The width of the facial nerve is similar to that of the abducens nerve. The vestibulocochlear nerve (VIII) is not visible on the endocast reconstructions. Just posterior to the endosseous labyrinth, two foramina pierce the medial surface of the exoccipital adjacent to its ventral surface. The most anterior one is for the exit of the glossopharyngeal nerve (IX), which represents the largest cranial nerve (Fig. 3A-B and 4A), and the dorso-posteriorly foramen is for the vagus-accessory nerves $(\mathrm{X}+\mathrm{XI})$. Branches of the hypoglossal nerve (XII) pass through the three foramina in each of the exoccipitals, ventrally to the vagus-accessory nerves. The branches of the hypoglossal nerve are thin and arranged in a triangular pattern on each side of the medulla oblongata. 


\section{Endosseous Labyrinth}

Left and right endosseous labyrinths of D1-8213 are preserved, except the most ventral part of the lagena (Fig. 4B). The endosseous labyrinth is positioned ventrally to the cerebellum and its general aspect is similar to the plesiosaurian endosseous labyrinths already described by Evans (1999) and Neenan et al. (2017). The vestibule is rounded and the semicircular canals are square-shaped in lateral view, robust and low (Fig. 4B). Even if the true ventral extent of the lagena is unknown, it seems to be relatively short, robust and uncoiled. The endosseous labyrinth is approximately $24 \mathrm{~mm}$ tall and has a maximum width of $20 \mathrm{~mm}$ at the level of the semi-circular canals. The anterior semicircular canal (asc) is longer than the two other ones, which seem to be similar in length. Diameter comparisons indicates that the posterior semicircular canal (psc) is the thickest one (psc >asc >1sc). The dorsal margins of both anterior and posterior semicircular canals are at the same level (Fig. 4B). The angles formed between the anterior and posterior semicircular canals is approximately $113^{\circ}$; $96^{\circ}$ between the anterior and lateral semicircular canals and $84^{\circ}$ between the posterior and lateral semicircular canals. The anterior and posterior canals meet at the common crus (Fig. 4B), which is approximately of similar diameter as the canals themselves. In lateral view (Fig. 4B), a larger gap is observed between the anterior canal and the common crus than between the posterior canal and the crus (Fig. 4B).

\section{Comparisons with Extinct and Extant Marine Reptiles}

Endocranial reconstructions of either extinct or extant reptilian taxa living in marine ecosystems are scarce. Data are limited to a few endocranial studies dealing exclusively or 
partially with extant aquatic snakes, marine turtles, ichthyosaurians, mosasauroids, thalattosuchians and sauropterygians (see Table 1 for a review of the literature). Endocranial comparisons with the existing data show that plesiosaurians exhibit a unique combination of endocranial characteristics not found in any other extant or extinct marine reptile. Plesiosaurian olfactory tracts, elongated anteroposteriorly and not separated along their length (Fig. 3), are similar to those reported in mosasauroids and nothosaurians (Camp, 1942; Voeten et al., 2018) but differ from the short olfactory tracts observed in turtles (Paulina-Carabajal et al., 2013) and the more or less separated olfactory tracts found in snakes (Allemand et al., 2017c), thalattosuchians (e.g., Pierce et al., 2017) and ichthyosaurs (e.g., Marek et al., 2015). Plesiosaurian endocasts are nearly linear (Fig. 3), both the anterior and posterior parts being at the same dorsoventral level, similarly as reported in snakes (Allemand et al., 2017c), thalattosuchians (e.g., Pierce et al., 2017), nothosaurians (Voeten et al., 2018) and turtles (Paulina-Carabajal et al., 2013), a condition differing from that of Placodus gigas (Neenan and Scheyer, 2012), in which the structure appears anteroposteriorly inclined and sigmoidal. The horizontal projection of the plesiosaurian pituitary differs from the tilted one observed in snakes (Allemand et al., 2017c) and thalattosuchians (e.g., Pierce et al., 2017). In plesiosaurians, the cerebellum seems strongly developed and easily discernible (Fig. 3). This differs from other marine reptiles, in which the cerebellum is not always distinguishable (snakes, turtles and Triassic sauropterygians; Neenan and Scheyer, 2012; Paulina-Carabajal et al., 2013; Allemand et al., 2017c; Voeten et al., 2018) or, when visible (thalattosuchians and ichthyosaurs; Marek et al., 2015; Pierce et al., 2017), is not as developed as in plesiosaurians.

\section{Intraspecific Variability}

The endocast of the holotype of Libonectes morgani, SMUMP 69120 (Carpenter, 1997 ) is similar to those of the two specimens of L. morgani studied here. Although the 
endocranial proportions are similar, there is, however, one noticeable difference in the ventral flexure of the endocast. The reconstruction of Carpenter (1997) shows that the cerebellum in SMUMP 69120 is located more ventrally than the plane defined by the olfactory tracts in lateral view, whereas in D1-8213 and SMNS 81783, both olfactory tracts and the cerebellum are in the same plane, resulting in a nearly horizontal endocast. Thus, among the three specimens of Libonectes morgani, SMUMP 69120 shows the more pronounced flexure of its endocast, whereas the skull of SMNS 81783 and D1-8213 show a more horizontal development of their brain cavities.

According to Giffin (1989), the main causes of the endocranial flexure are the absolute size of the skull and the relative size of the eyes. Smaller taxa tend to show an endocast with a more pronounced flexure than larger ones, the same pattern being observed in young individuals as compared to older ones of the same species (Giffin, 1989). The loss of the flexure would thus be a consequence of the increase in skull size. The skull growing at a higher speed than the brain, the latter has relatively more space in the larger individuals and "unfolds" (Hopson, 1979). Conversely, when the cranial cavity is relatively smaller, the brain presents a more or less pronounced "S" shape, with an anterior part located higher than the posterior one (Hopson, 1979). In addition, large eyes, which could be related to a juvenile state within a species or to an ecologic adaptation to a particular lifestyle (e.g., nocturnality, see Konishi et al., 2016), may compress the occipital region as well as the brain and could increase the flexure (Starck, 1979). Surprisingly, the specimen of Libonectes that presents the longest skull (SMUMP 69120: about $500 \mathrm{~mm}$ in length, see Carpenter, 1997) shows the more pronounced flexure. The two other specimens (are smaller (SMNS 81783 is 295 and D1-8213 $350 \mathrm{~mm}$ long) but show no flexure of the endocast. Size being usually correlated with the age of the individuals, this observation thus questions Giffin's (1989) assumption. Thus, the 
plesiosaurian endocranial flexure does not necessarily correspond to an ontogenetical variation, but it could possibly reflect an individual variability.

\section{Plesiosaurian Pineal Organ}

Both the parapineal organ (also named parietal eye or pineal eye) housed in the parietal foramen and the associated pineal organ form the pineal complex (Smith et al., 2018). In reptiles, the parapineal organ contains highly developed photoreceptor cells capable of transducing photic information and assuming the/a predominant photosensory role (Concha and Wilson, 2001; Smith et al., 2018). In addition, the pineal organ of reptiles, which contains rudimentary photoreceptor cells, is retained as a neuroendocrine gland governing melatonin secretion and distribution (Falcón, 1999). The pineal complex in these taxa influences behaviour, body temperature regulation, seasonal cycles, spatial orientation and regulation of the circadian rhythm (Quay, 1979; Tosini, 1997).

It is not possible to distinguish the parapineal organ from the pineal one based on endocranial reconstructions, in both extinct and extant non-avian reptiles. A pineal complex has been reported for various clades of extinct marine reptiles such as mosasauroids (Camp, 1942; Allemand et al., unpub. data 2017b), ichthyosaurians (Marek et al., 2015) and Triassic sauropterygians (Neenan and Scheyer, 2012; Voeten et al., 2018). On the contrary, although a pineal complex occurs in extant turtles and snakes (Wyneken, 2003, 2007), the structure is covered by the dorsal longitudinal vein (Aurboonyawat et al., 2008) and not visible from the endocast (Paulina-Carabajal et al., 2013; Allemand et al., 2017c). In this study, we hypothesize that the bulge visible on the dorsal surface of the endocast of the three plesiosaurian specimens (Fig. 3) could correspond to a small pineal complex. Its position, at the junction between the parietals, coincides with the parietal foramen located within the parietals in the undetermined polycotylid MNHN F-GOU14 (Allemand et al., 2018). On the 
contrary, the parietal foramen in the elasmosaurid L. morgani specimen SMNS 81783 is located more anteriorly than the identified pineal organ, at the level of the postorbital bar and above the olfactory canals (Allemand et al., 2017a). Such anteriorly located parietal foramen, reported in the elasmosaurid Callawayasaurus colombiensis (Welles, 1952) but possibly also in another elasmosaurid, Terminonatator ponteixensis (Sato, 2003), is found in different reptilian clades (e.g., squamates Lacertidae, Iguanidae) and depends principally upon increasing elevation of the forebrain that reflect an increase in the size of the orbit (Quay, 1979). Thus, such variability in the position of the plesiosaurian parietal foramen could be related to morphological modifications associated to the short skull length and the relatively high position of the orbit in Elasmosauridae compared to Polycotylidae (e.g., Carpenter, 1997).

The pineal complex among extinct marine reptiles displays a great variability in size. According to Holloway et al. (2013), it seems that the relative size of the pineal organ in nonavian reptiles is reduced, following reduction of the parietal foramen. Indeed, the small parietal foramen and the reduced pineal organ observed in the elasmosaurid Libonectes differ from the medium-sized pineal organ that is associated to a relatively larger parietal foramen in the undetermined polycotylid (Allemand et al., 2018), but also in mosasauroids, ichthyosaurians and Triassic sauropterygians (Neenan and Scheyer, 2012; Marek et al., 2015; Connolly, 2016; Voeten et al., 2018). However, the exact ecological functions of such variability in size are still unclear. In extant lizards, it is suggested that the size of the pineal complex strongly correlates with latitude, species restricted to high latitudes having a larger pineal complex, probably for detecting light, than low latitude ones (Gundy et al., 1975; Ralph, 1975). However, recent quantitative studies from both extinct (mosasauroids: Connolly, 2016) and extant (Liolaemus lizards: Labra et al., 2010) squamates question this hypothesis by showing no correlation between the size of the pineal complex and latitude. 
Instead, Labra et al. (2010) found a weak relation between the size of the pineal complex and thermal regulation and corroborate the particular role of the pineal complex in the "finetuning" thermoregulation already suggested for extant lizards (Hutchison and Kosh, 1974; Ralph et al., 1979). In addition, in mammals, it was hypothesized that the reduction and loss of the pineal complex reflects the transition from ectothermy to endothermy (Benoit et al., 2016). Although the small elasmosaurid pineal complex could be related to the ability to regulate its body temperature independently from the surrounding water temperature (Bernard et al., 2010), the large pineal complex found in non-elasmosaurid plesiosaurians and ichthyosaurians, which have also an elevated metabolic rate (Bernard et al., 2010), questions this assumption.

The reduction of the pineal complex in elasmosaurids, which occurred independently in pseudosuchians, theropods and sauropods (Holloway et al., 2013), remains difficult to explain. Although it could be related to differences in both photoreceptive and neuroendocrine functions, additional studies illustrating variability in the reptilian pineal complex and associated physiological roles are needed to better interpret this structure.

\section{Plesiosaurian Endocast: Functional Hypotheses}

Several studies in extant mammals and reptiles (including birds) have shown that the endocast morphology bears both phylogenetical and ecological signals, and could provide, similar to the brain, some information about species sensory abilities (e.g., Macrini et al., 2006, 2007; Corfield et al., 2015; Allemand et al., 2017c). An endocast does not represent the morphology of the brain and brainstem only, but also the contours of associated brain tissues in contact with the internal surface of the braincase, such as the meninges, the blood vessels, the cerebrospinal fluid and the venous system (Witmer and Ridgely, 2009). Depending on clades, these tissues may account for a significant proportion of the endocranial space 
(Witmer et al., 2008) and strongly affect the degree to which the endocast reflects the brain. In non-avian reptiles, although snakes and amphisbaenians are known to have a brain that fills most of the endocranial space (Nieuwenhuys et al., 1998), a wide range of brain vs. endocranial space proportions occur depending on clades (Kim and Evans, 2014) or ontogenetic stage (Jirak and Janacek, 2017). Here, the absence of extant representatives for plesiosaurians and their ambiguous phylogenetic bracketing prevent making strong biological inferences based on their endocasts, but comparisons with other marine reptiles can allow to highlight some traits and attempt preliminary paleobiological suggestions.

Little is known about plesiosaurian sensorial abilities, and how they differ depending on their mode of adaptation to an aquatic life and niche partitioning. A few studies have suspected: 1) underwater olfaction based on the postero-dorsal position of external nostrils related to the internal nares (Cruickshank et al., 1991, but see Buchy et al., 2006); 2) a possible well-developed and binocular vision based on the large size and forward-looking position of the orbits and the presence of sclerotic plates (Andrews, 1913; Shuler, 1950; Forrest, 2000); 3) a system involved in prey detection similar to crocodile pressure receptors or shark electroreceptors based on extensive bifurcating neurovascular channels (Foffa et al., 2014).

From the endocasts described herein, discussing olfaction abilities appears difficult since the olfactory bulbs seem very incomplete. However, endocranial reconstructions show that both the optic lobes and the cerebellum seem to constitute important components of the plesiosaurian endocast. Indeed, although these structures may be covered dorsally by the venous system (Aurboonyawat et al., 2008) affecting strongly their sizes, both the optic lobes and the cerebellum form distinct bulges from the rest of the endocast, whereas in other marine reptiles such distinction is more difficult (e.g, Voeten et al., 2018). 
In vertebrates, it is generally admitted that, as the superficial layers of the optic lobes receive visual inputs from the retina through the optic (II) nerves (Butler and Hodos, 2005), their size is correlated to the importance of vision (e.g., Jerison, 1973; Butler and Hodos, 2005). Conversely, the more internal layers of the optic lobes are involved in auditory and somatosensory inputs (e.g., Buttler and Hodos, 2005). From endocasts, it is not possible to determine which layer of the optic lobe is more developed than the other as only the external morphology of the structure is visible. However, the relatively large size of the plesiosaurian optic lobes could suggest well-developed abilities to localize preys or predators, from vision and/or auditory inputs.

The cerebellum is multisensory and plays an important role in cognitive functions, such as touch, proprioception, vision, hearing, and has a role in maintaining postural equilibrium (Wyneken, 2007), and influences locomotor behaviour (Thach and Bastian, 2004; Buttler and Hodos, 2005). Among vertebrates, the cerebellum shows a great variability in size, shape and organization (Butler and Hodos, 2005) that is difficult to interpret. In nonavian reptiles, this structure generally has a modest size and forms a flat plate just posterior to the optic lobes (Butler and Hodos, 2005). Since, the plesiosaurian cerebellum differs from that of all non-avian reptiles, including turtles that share a similar mode of sub-aquatic flight locomotion (Paulina-Carabajal et al., 2013), or other highly aquatic extinct taxa such as ichthyosaurs (Marek et al., 2015), such enlargement could be related to the relative length of the neck and its role in maintaining postural equilibrium. The investigation of the endocast morphology of short-necked taxa should allow to verify this hypothesis.

\section{Plesiosaurian Endosseous Labyrinth}

The endosseous labyrinth reconstructed for the elasmosaurid Libonectes morgani specimen D1-8213 exhibits the elasmosaurid morphology reported in Callawayasaurus 

colombiensis and Libonectes morgani specimen SMUMP 69120 by Neenan et al. (2017). It corresponds to a square appearance in lateral view, a compact, bulbous labyrinth, with a wide crus communis, as well as short and wide semicircular canals (Fig. 4B; Neenan et al., 2017:

Fig.1). However, Callawayasaurus exhibits a taller endosseous labyrinth than both Libonectes specimens (Neenan et al., 2017) resulting in a dorsal extension of both the posterior and anterior semicircular canals and a longer crus communis. Such variability could rely on a phylogenetic signal (e.g., Palci et al., 2017) but also be linked to ecological factors (e.g., Palci et al., 2018). According to Neenan et al. (2017), the labyrinth in sauropterygians is closely linked with both locomotor style and body proportions. However, both Callawayasaurus and Libonectes seem to have the same swimming mode, with a four-flippered underwater flight. In addition, both are characterized by an extreme elongation of the neck (respectively 56 and 48 cervical vertebrae in Callawayasaurus and Libonectes, Welles, 1952; Sachs and Kear, 2015) and display similar body proportions. Thus, the ecologic arguments here do not seem sufficient to explain such difference, and the phylogenetic signal reflected by the labyrinth must be confirmed by adding elasmosaurid endosseous labyrinth.

\section{CONCLUSIONS}

plesiosaurian endocasts and provides additional information about other delicate structures such as the endosseous labyrinth and cranial nerves. Endocranial comparisons with other plesiosaurians allow to discuss their intraspecific and interspecific variability. The endocranial flexure is thought as an individual variability rather than an ontogenetic one, and the differences observed on the elasmosaurid endosseous labyrinth could reflect more a phylogenetic signal than an ecological one. In addition, we suggest that the possible pineal 
organ observed on the two endocasts of Libonectes and its position related to the more anteriorly located parietal foramen is part of morphological modifications associated to the elasmosaurid skull length and the high position of their orbit. Finally, comparisons with other marine reptiles allow a few preliminary paleobiological suggestions concerning the welldeveloped plesiosaurian abilities in vision and audition, and question the role of the cerebellum in long-necked plesiosaurians. This study is part of pioneer works relative to plesiosaurian neuroanatomy. Biological inferences based on endocast features should naturally be made with caution as several other non-functional and non-phylogenetical factors may affect the endocast morphology and as data available are extremely scarce. Further investigations on plesiosaurian endocast should enable to better evaluate which structures are preserved along their evolutionary history and which ones are modified for a specific ecological and/or functional adaptation.

\section{ACKNOWLEDGMENTS} the LabEx ANR-10-LABX-0003-BCDiv, in the program "Investissements d'avenir" ANR11-IDEX-0004-02. We are grateful to the Staatliches Museum für Naturkunde Stuttgart for the loan of the specimen SMNS 81783 and to E. Maxwell for access to the collection of the Stuttgart museum. We are grateful to the Rhinopolis Museum for the loan of the specimen D1-8213. We thank the AST-RX platform at the MNHN for access to the CT-scan and M. Garcia-Sanz (MNHN, UMS 2700 OMSI) for producing the CTscans. We are also thankful to the 3D platform (UMR 7207, CR2P, MNHN) for giving access to the 3D imaging facilities. Finally, the authors want to thank R. F. O'Keefe (editor), J. M. Neenan (reviewer) and one anonymous reviewer for helpful comments and suggestions. 
450

45Abele, A. 2017. Digital reconstruction of skull and endocranium of the Cretaceous ichthyosaur 452 Platypterygius longmani from Australia, regarding sensory perception and internal structures;

453 pp. 41 in O. Hampe, D. Schwarz and M. Voss (eds), 8th International meeting Secondary 454 adaptation of Tetrapods to life in water. Berlin, Germany, 3-8 April 2017.

455gassiz, L. 1833. Recherches sur les Poissons Fossiles, Vol. I. Neuchâtel, Imprimaire de 456 Petitpierre, France, 17 pp.

45yllemand, R., N. Bardet, A. Houssaye, and P. Vincent. 2017a. Virtual re-examination of a 458 plesiosaurian specimen (Reptilia, Plesiosauria) from the Late Cretaceous (Turonian) of 459 Goulmima (Southern Morocco) thanks to computed tomography. Journal of Vertebrate $460 \quad$ Paleontology 37:e1325894

46Allemand, R., P. Vincent, A. Houssaye, and N. Bardet. 2017b. Endocranial microtomographic 462 study of marine reptiles (Plesiosauria and Mosasauroidea) from the Turonian (Late 463 Cretaceous) of Morocco: palaeobiological and behavioral implications. Ph.D. dissertation, 464 Muséum National d'Histoire Naturelle, Paris, France, 285 pp.

465llemand, R., P. Vincent, A. Houssaye, and N. Bardet. 2018. New plesiosaurian specimens 466 (Reptilia, Plesiosauria) from the Late Cretaceous (Turonian) of Goulmima (Southern 467 Morocco). Cretaceous Research 82:83-98.

468llemand, R., R. Boistel, Z. Blanchet, R., Cornette, N., Bardet, P., Vincent, and A. Houssaye, A. 469 2017c. Comparative morphology of snake (Squamata) endocasts: evidence of phylogenetical 470 and ecological signals. Journal of Anatomy 231:849-868. 
47Andrews, C. W. 1913. A descriptive catalogue of the Marine Reptiles of the Oxford Clay. Based on 472 the Leeds Collection in British Museum (Natural History), Part II. British Museum (Natural 473 History), London, 206 pp.

47Araújo, R., M. J. Polcyn, A. S. Schulp, O. Mateus, L. L. Jacobs, A. O. Goncalves, and M. L.

475 Morais. 2014. A new elasmosaurid from the early Maastrichtian of Angola and the 476 implications of girdle morphology on swimming style in plesiosaurs. Netherlands Journal of 477 Geosciences 94:109-120.

478urboonyawat, T., V. Pereira, T. Kring, F. Toulgoat, A. Churojana, and P. Lasjaunias. 2008. 479 Patterns of the Cranial Venous System from the Comparative Anatomy in Vertebrates: Part II. 480 The Lateral-Ventral Venous System. Interventional Neuroradiology 14:21-31. 4\&ardet, N., X. Pereda Suberbiola, and N. E. Jalil. 2003. A new mosasauroid (Squamata) from the 482 Late Cretaceous (Turonian) of Morocco. Comptes Rendus Palevol 2:607-616.

$4 \$$ ardet, N., J. Falconnet, V. Fischer, A. Houssaye, S. Jouve, X. Pereda Suberbiola, A. Perez-Garcia, 484 J-C. Rage, and P. Vincent. 2014. Mesozoic marine reptile palaeobiogeography in response to 485 drifting plates. Gondwana Research 26:869-887.

4\&6enoit, J., F. Abdala, P. R. Manger, and B. S. Rubidge. 2016. The sixth sense in mammalian 487 forerunners: Variability of the parietal foramen and the evolution of the pineal eye in South 488 African Permo-Triassic eutheriodont therapsids. Acta Palaeontologica Polonica 61:777-789. 4\&3enson, R. B. J., M. Evans, and P. S. Druckenmiller. 2012. High diversity, low disparity and small 490 body size in Plesiosaurs (Reptilia, Sauropterygia) from the Triassic-Jurassic boundary. PLoS 491 ONE 7(3): e31838. doi:10.1371/journal.pone.0031838.

4\$2ernard, A., C. Lécuyer, P. Vincent, R. Amiot, N. Bardet, E. Buffetaut, G. Cuny, F. Fourel, F. 493 Martineau, J-M. Mazin, and A. Prieur. 2010. Regulation of body temperature by some 494 Mesozoic marine reptiles. Science 328:1379-1382. 
4\$\$lainville, H. D. de. 1853. Lettre de Monsieur de Blainville; pp. 103-13 in E. Deslongchamps (ed), 496 Lettres sur les Crocodiles vivants et fossiles. Mémoires Société Linnéenne de Normandie, 497 Caen, France.

498ronn, H. G. 1841. Über die fossilen Gaviale der Lias Formation und der Oolithe. Archiv für 499 Naturgeschichte, Berlin 8:77-82.

5dBrusatte, S. L., A. Muir, M. T. Young, S. Walsh, L. Steel, and L. M. Witmer. 2016. The braincase 501 and neurosensory anatomy of an Early Jurassic marine crocodylomorph: Implications for 502 crocodylian sinus evolution and sensory transitions. The Anatomical Record 299:1511-1530. 5d3uchy, M. C., E. Frey, and S. W. Salisbury. 2006. The internal cranial anatomy of the Plesiosauria 504 (Reptilia, Sauropterygia): evidence for a functional secondary palate. Lethaia 39:289-303. 5dButler, A. B., and W. Hodos. 2005. Comparative Vertebrate Neuroanatomy: Evolution and 506 Adaptation. John Wiley and Sons, Inc., Hoboken, NJ, U.S.A., 744 pp.

5@Zaldwell, M. W. 1997. Modified perichondral ossification and the evolution of paddle-like limbs in 508 ichthyosaurs and plesiosaurs. Journal of Vertebrate Paleontology 17:534-547.

509amp, C. L. 1942. California mosasaurs. Berkeley, California, University of California Press, 510 U.S.A., $67 \mathrm{pp}$.

51larpenter, K. 1997. Comparative cranial anatomy of two North American Cretaceous plesiosaurs; 512 pp. 191-216 in J. M. Callaway and E. L. Nicholls (eds.), Ancient Marine Reptiles. San Diego 513 Academic Press, California.

514larke, J., and S. Etches. 1992. Predation among Jurassic reptiles. Proceedings of the Dorset 515 Natural History and Archaeological Society 113:202-205.

516oncha, M. L., and S. W. Wilson. 2001. Asymmetry in the epithalamus of vertebrates. The Journal 517 of Anatomy 199:63-84. 
518onnolly, A. 2016. Exploring the Relationship between Paleobiogeography, Deep-Diving

519 Behavior, and Size Variation of the Parietal Eye in Mosasaurs. Master dissertation, University

520 of Kansas, U.S.A., 43 pp.

5x1orfield, J. R., K. Price, A. N. Iwaniuk, C. Gutierrez-Ibanez, T. Birkhead, and D. R. Wylie. 2015.

522 Diversity in olfactory bulb size in birds reflects allometry, ecology and phylogeny. Frontiers

523 in Neuroanatomy 9:doi:10.3389/fnana.2015.00102.

524ruickshank, A. R., P. G. Small, and M. A. Taylor. 1991. Dorsal nostrils and hydrodynamically 525 driven underwater olfaction in plesiosaurs. Nature 352:62-64.

5ð6uthbertson, R. S., H. C. Maddin, R. B. Holmes, and J. S. Aanderson. 2015. The braincase and 527 endosseous labyrinth of Plioplatecarpus peckensis (Mosasauridae, Plioplatecarpinae), with 528 functional implications for locomotor behavior. The Anatomical Record 298:1597-1611. 5 đ9dinger, T. 1921 Über Nothosaurus. II. Zur Gaumenfrage. Senckenbergiana 3:193-205. 5F®dinger, T. 1928. Über einige fossile Gehirne. Paläontologische Zeitschrift 9:379-402. 5¥ttachfini, E. M., and B. Andreu. 2004. Le Cénomanien et le Turonien de la plate-forme 532 Préafricaine du Maroc. Cretaceous Research 25:277-302.

5ł3vans, M. 1999. A new reconstruction of the skull of the Callovian elasmosaurid plesiosaur 534 Muraenosaurus leedsii Seeley. Mercian Geologist 14:191-198.

5 $35 a l c o n$, J. 1999. Cellular circadian clocks in the pineal. Progress in neurobiology 58:121-162. 5F6offa, D., J. Sasson, A. R. Cuff, M. N. Mavrogordato, and M. J. Benton. 2014. Complex rostral 537 neurovascular system in a giant pliosaur. Naturwissenschaften 101:453-456.

5¥80rrest, R. 2000. A large rhomaleosaurid pliosaur from the Upper Lias of Rutland. Mercian 539 Geologist 15:37-40.

54Garman, S. 1880. On certain species of Chelonioidae. Bulletin of the Museum of Comparative 541 Zoology, Harvard 6:123-126. 
54جasparini, Z. L., and D. Dellapé. 1976. Un nuevo cocodrilo marino (Thalattosuchia,

543 Metriorhynchidae) de la Formacion Vaca Muerta (Jurasico, Titoniano) de la provincia de 544 Neuquen. Actas I Congreso Geologico Chileno 1:1-21.

545iffin, E. B. 1989. Pacycephalosaur Paleoneurology (Archosauria: Ornithischia). Journal of 546 Vertebrate Paleontology 9:67-77.

5477undy, G. C., C. L. Ralph, and G. Z. Wurst. 1975. Parietal eyes in lizards: zoogeographical 548 correlates. Science 190:671-673.

549errera, Y. 2015. Metriorhynchidae (Crocodylomorpha: Thalattosuchia) from Upper Jurassic550 Lower Cretaceous of Neuquén Basin (Argentina), with comments on the natural casts of the 551 brain. Publicación Electrónica de la Asociación Paleontológica Argentina 15 :159-171.

54terrera, Y., M. S. Fernandez, and Z. Gasparini. 2013. The snout of Cricosaurus araucanensis: a 553 case study in novel anatomy of the nasal region of metriorhynchids. Lethaia 46:331-340. 544errera Y, J. M. Leardi, and M. S. Fernández. 2018. Braincase and endocranial anatomy of two 555 thalattosuchian crocodylomorphs and their relevance in understanding their adaptations to the 556 marine environment. PeerJ 6:e5686 https://doi.org/10.7717/peerj.5686

5łtolloway, W. L., K. M. Claesson, and F. R. O’Keefe. 2013. A virtual phytosaur endocast and its 558 implications for sensory system evolution in archosaurs. Journal of Vertebrate Paleontology $559 \quad 33: 848-857$.

54ஞopson, J. A. 1979. Paleoneurology; pp. 39-146 in C. Gans, R. G. Northcutt, and P. Ulinsky (eds), 561 Biology of the Reptilia. Vol. 9A. London: Academic Press.

5đdurlburt, G. R., Ridgely, R. C., Witmer, L. M. 2013. Relative size of brain and cerebrum in 563 tyrannosaurid dinosaurs: an analysis using brainendocast quantitative relationships in extant 564 alligators; pp. 134-155 in J. M. Parrish, R. E. Molnar, P. J. Currie, and E. B. Koppelhus (eds), 565 Tyrannosaurid paleobiology. Indiana University Press, Bloomington. 
5Æ6utchison, V. H., and R. J. Kosh. 1974. Thermoregulatory function of the parietal eye in the lizard 567 Anolis carolinensis. Oecologia 16:173-177.

568rison, H. J. 1973. Evolution of the brain and intelligence. New York Academic, 482 pp.

569̊rak, D., and J. Janacek. 2017. Volume of the crocodilian brain and endocast during ontogeny. 570 PLoS ONE 12:doi.org/10.1371/journal.pone.0178491

5 Kennedy, W. J., A. S. Gale, D. J. Ward, and C. J. Underwood. 2008. Early Turonian ammonites 572 from Goulmima, southern Morocco. Bulletin de l'Institut Royal des Sciences Naturelles de 573 Belgique 78:149-177.

574im, R., and D. Evans D. 2014. Relationships among brain, endocranial cavity, and body sizes in 575 reptiles; pp. 159 in E. Maxwell and J. Miller-Camp (eds), Society of Vertebrate Paleontology 576 74th Annual Meeting. Berlin, Germany, November 5-8, 2014.

5攵ishida, T., J. G. M. Thewissen, T. Hayakawa, H. Imai, and K. Agata. 2015. Aquatic adaptation 578 and the evolution of smell and taste in whales. Zoological Letters 1:1-9.

5 \$oken, E. 1893. Beitrage zur Kenntnis der Gattung Nothosaurus. Zeitschrift der deutschen 580 geologischen Gesellschaft 45:337-377.

5đonishi, T., M. W. Caldwell, T. Nishimura, K. Sakurai, and K. Tanoue. 2016. A new halisaurine 582 mosasaur (Squamata: Halisaurinae) from Japan: the first record in the western Pacific realm 583 and the first documented insights into binocular vision in mosasaurs. Journal of Systematic 584 Palaeontology 14:809-839.

585abra, A., K. L. Voje, H. Seligmann, and T. F. Hansen. 2010. Evolution of the third eye: a 586 phylogenetic comparative study of parietal-eye size as an ecophysiological adaptation in 587 Liolaemus lizards. Biological journal of the Linnean Society 101:870-883.

58\&eidy, J. 1865. Cretaceous reptiles of the United States. Washington, Smithsonian Institution, 589 U.S.A., 135 pp. 
590innaeus, C. 1758. Systema Naturae per regna tria naturae, secundum classes, ordines, genera, 591 species, cum characteribus, differentiis, synonymis, locis. Tomus II. Editio duodecima, 592 reformata, Laurentius Salvius, Stockholm, Holmiae, 824 pp.

593innaeus, C. 1766. Systema naturæ per regna tria naturæ, secundum classes, ordines, genera, 594 species, cum characteribus, differentiis, synonymis, locis. Tomus I. Editio duodecima, 595 reformata, Laurentii Salvii, Stockholm, Holmiae, 532 pp.

596acrini, T. E., T. Rowe, and M. Archer. 2006. Description of a cranial endocast from a fossil 597 platypus, Obdurodon dicksoni (Monotremata, Ornithorhynchidae), and the relevance of 598 endocranial characters to monotreme monophyly. Journal of Morphology 267:1000-1015. 599tacrini, T. E., T. Rowe, and J. L. VandeBerg. 2007. Cranial endocasts from a growth series of 600 Monodelphis domestica (Didelphidae, Marsupialia): A study of individual and ontogenetic 601 variation. Journal of Morphology 268:844-865.

6017arek, R. D., B. C. Moon, M. Williams, and J. Benton. 2015. The skull and endocranium of a 603 Lower Jurassic ichthyosaur based on digital reconstructions. Palaeontology 58:723-742. 60Alassare, J. A. 1987. Tooth morphology and prey preference of Mesozoic marine reptiles. Journal 605 of Vertebrate Paleontology 7:121-137.

606assare, J. A. 1988. Swimming capabilities of Mesozoic marine reptiles: implications for method 607 of predation. Paleobiology 14:187-205.

6d8IcGowan, C. 1973. The cranial morphology of the Lower Liassic latipinnate ichthyosaurs of 609 England. Bulletin of the British Museum (Natural History), Geology 24:1-109.

619cHenry, C. R., A. G. Cook, and S. Wroe. 2005. Bottom-feeding plesiosaurs. Science 310: 75. 61Münster, G. 1834. Vorliufige Nachricht fiber einige neue Reptilien im Muschelkalke von Baiern. 612 Neues Jahrbuch ffir die Mineralogie, Geognosie, Geologie und Petrefactenkunde 1834:521613 527. 
614eenan, J. M., and T. M. Scheyer. 2012. The braincase and inner ear of Placodus gigas

615 (Sauropterygia, Placodontia), a new reconstruction based on micro-computed tomographic 616 data. Journal of Vertebrate Paleontology 32:1350-1357.

61Xeenan, J. M., T. Reich, S. W. Evers, P. S. Druckenmiller, D. F. A. E. Voeten, J. N. Choiniere, P.

618 M. Barrett, S. E. Pierce, and R. B. J. Benson. 2017. Evolution of the Sauropterygian Labyrinth 619 with Increasingly Pelagic Lifestyles. Current Biology 27:3852-3858.

620ieuwenhuys, R., H. J. ten Donkelaar, and C. Nicholson. 1998. The Central Nervous System of 621 Vertebrates. Berlin: Springer, 2214 pp.

622'Keefe, R. F. 2001. A cladistic analysis and taxonomic revision of the Plesiosauria (Reptilia:

623 Sauropterygia). Acta Zoologica Fennica 213:1-63.

624'Keefe, R. F. 2002. The evolution of plesiosaur and pliosaur morphotypes in the Plesiosauria 625 (Reptilia: Sauropterygia). Paleobiology 28:101-112.

620'Keefe, R. F., and L. M. Chiappe. 2011. Viviparity and K-selected life history in a Mesozoic 627 marine plesiosaur (Reptilia, Sauropterygia). Science 333:870-873.

6ð'Keefe, R. F., R. A. Otero, S. Soto-Acuña, J. P. O'Gorman, S. J. Godfrey, and S. Chatterjee. 2017. 629 Cranial anatomy of Morturneria seymourensis from Antarctica, and the evolution of filter 630 feeding in plesiosaurs of the Austral Late Cretaceous. Journal of Vertebrate Paleontology 631 37:doi:10.1080/02724634.2017.1347570

6尹2alci, A., M. N. Hutchinson, M. W. Caldwell, and M. S. Lee. 2017. The morphology of the inner 633 ear of squamate reptiles and its bearing on the origin of snakes. Royal Society open science 634 4:doi: 10.1098/rsos.170685

635alci, A., M. N. Hutchinson, M. W. Caldwell, and J. Scanlon. 2018. Palaeoecological inferences for 636 the fossil Australian snakes Yurlunggur and Wonambi (Serpentes, Madtsoiidae). Royal 637 Society Open Science 5:doi:10.1098/rsos.172012 
6\$8aulina-Carabajal, A. P., J. Sterli, J. Muller, and A. Hilger. 2013. Neuroanatomy of the marine 639 Jurassic turtle Plesiochelys etalloni (Testudinata, Plesiochelyidae). PLoS ONE 640 8:doi:10.1371/journal.pone.0069264

64lictet, F. J., and A. Humbert. 1857. Description d'une émyde nouvelle (Emys Etalloni) du terrain 642 jurassique supérieur des environs de St-Claude; pp. 256-273 in F. J. Pictet (ed), Matériaux 643 pour la paléontologie suisse. Première série, Genève, Suisse.

644ierce, S. E., M. Williams, M., and R. B. J. Benson. 2017. Virtual reconstruction of the endocranial 645 anatomy of the early Jurassic marine crocodylomorph Pelagosaurus typus (Thalattosuchia). 646 PeerJ 5:e3225.

64Quay, W. B. 1979. The parietal eye-pineal complex; pp. 245-406 in C. Gans, R. G. Northcutt, and 648 P. Ulinski (eds), Biology of the Reptilia. Volume 9 Neurology A. London, Academic Press. 649alph, C. L. 1975. The pineal gland and geographical distribution of animals. International Journal 650 of Biometeorology 19:289-303.

65lalph, C. L., B. T. Firth, and J. S. Turner. 1979. The role of the pineal body in ectotherm 652 thermoregulation. American Zoologist 19:273-293.

653othschild, B. M., and G. W. Storrs. 2003. Decompression syndrome in plesiosaurs (Sauropterygia: 654 Reptilia). Journal of Vertebrate Paleontology 23:324-328.

655achs, S., and B. P. Kear. 2015. Postcranium of the paradigm elasmosaurid plesiosaurian 656 Libonectes morgani (Welles, 1949). Geological Magazine 152:694-710.

6577achs, S., J. Lindgren, and M. Siversson. 2015. A partial plesiosaurian braincase from the Upper 658 Cretaceous of Sweden. Geological Society, London, Special Publications 434: 293-301. 659achs, S., J. J. Hornung, and B. P. Kear. 2016. Reappraisal of Europe's most complete Early 660 Cretaceous plesiosaurian: Brancasaurus brancai Wegner, 1914 from the "Wealden facies" of 661 Germany. PeerJ 4:doi:10.7717/peerj.2813 
662ato, T. 2003. Terminonatator ponteixensis, a new elasmosaur (Reptilia; Sauropterygia) from the 663 Upper Cretaceous of Saskatchewan. Journal of Vertebrate Paleontology 23:89-103.

66łato, T., and K. Tanabe. 1998. Cretaceous plesiosaurs ate ammonites. Nature 394:629-630.

665ato, T., X.C. Wu, A. Tirabasso, A., and P. Bloskie. 2011. Braincase of a polycotylid plesiosaur 666 (Reptilia: Sauropterygia) from the Upper Cretaceous of Manitoba, Canada. Journal of 667 Vertebrate Paleontology 31:313-329.

6 eley, H. G. 1880. Note on the cranial characters of a large teleosaur from the Whitby Lias 669 preserved in the Woodwardian museum of the University of Cambridge, indicating a new 670 species, Teleosaurus eucephalus. Quarterly Journal of the Geological Society 36: 627-634. 6\$tennikov, A. G., and M. S. Arkhangelsky. 2010. On a typical Jurassic sauropterygian from the 672 Upper Triassic of Wilczek Land (Franz Josef Land, Arctic Russia). Paleontological Journal $673 \quad 44: 567-572$.

67huler, E. W. 1950. A new elasmosaur from the Eagle Ford Shale of Texas. Fondren Science Series $675 \quad 1: 1-33$

67mith, K. T., B-A. S. Bhullar, G. Köhler, and J. Habersetzer. 2018. The only known jawed 677 vertebrate with four eyes and the Bauplan of the pineal complex. Current Biology 28: 11016781107.

67tarck, D. 1979. Cranio-cerebral relations in Recent reptiles; pp. 1-38 in C. Gans, R. G. Northcutt, 680 and P. Ulinski (eds.), Biology of the Reptilia. Vol. 9 (Neurology A). Academic Press, 681 London.

682torrs, G. W. 1995. A juvenile specimen of ?Plesiosaurus sp. from the Lias (Lower Jurassic, 683 Pliensbachian) near Charmouth, Dorset, England. Proceedings of the Dorset Natural History 684 and Archaeological Society 116:71-76.

685arlo, L. B. 1959. Pliosaurus brachyspondylus (Owen) from the Kimeridge Clay. Palaeontology 686 $1: 283-291$. 
68Thach, W. T., and A. J. Bastian. 2004. Role of the cerebellum in the control and adaptation of gait 688 in health and disease. Progress in brain research 143:353-366.

6800sini, G. 1997. The pineal complex of reptiles: physiological and behavioral roles. Ethology 690 Ecology \& Evolution 9:313-333.

69tandelli, D. 1761. Epistola de holothurio, et testudine coriacea ad celeberrimum Carolum 692 Linnaeum equitem naturae curiosum Dioscoridem II. Conzatti, Padua, 12 pp. 698ignaud, P. 1998. Une Nouvelle espèce de Steneosaurus (Thalattosuchia, Teleosauridae) dans le 694 Callovien du Poitou (France) et la systématique des Steneosaurus longirostres du Jurassique 695 moyen d'Europe occidentale. Palaeovertebrata 27:19-44.

696ignaud, P., and Z. B. Gasparini. 1996. New Dakosaurus (Crocodylomorpha, Thalattosuchia) from 697 the Upper Jurassic of Argentina. Comptes Rendus de l'Académie des Sciences Paris 322:245698250.

69ஞincent, P., R. Allemand, P. D. Taylor, G. Suan, E. E. Maxwell. 2017. New insights on the 700 systematics, palaeoecology and palaeobiology of a plesiosaurian with soft tissue preservation 701 from the Toarcian of Holzmaden, Germany. The Science of Nature 104:51.

702incent, P., N. Bardet, X. Pereda Suberbiola, B. Bouya, M. Amaghzaz, and S. Meslouh. 2011. 703 Zarafasaura oceanis, a new elasmosaurid (Reptilia: Sauropterygia) from the Maastrichtian 704 Phosphates of Morocco and the palaeobiogeography of latest Cretaceous plesiosaurs. 705 Gondwana Research 19:1062-1073.

706̆oeten, D. F. A. E., T. Reich, R. Araujo, and T. M. Scheyer. 2018. Synchrotron microtomography 707 of a Nothosaurus marchicus skull informs on nothosaurian physiology and neurosensory 708 adaptations in early Sauropterygia. PLoS ONE 13: doi.org/10.1371/journal.pone.0188509 70 $\$$ ade, M. 1990. A review of the Australian Cretaceous longipinnate ichthyosaur Platypterygius 710 (Ichthyosauria: Ichthyopterygia). Memoirs of the Queensland Museum 28:115-137. 
71Welles, S. P. 1952. A review of the North American Cretaceous elasmosaurs. University of 712 California, Publications in Geological Sciences 29:47-144.

713enz, S. 1968. Contribution à l'étude du genre Metriorhynchus. Crâne et moulage endocrânien de 714 Metriorhynchus superciliosus. Annales de Paléontologie (Vertébrés) 54: 149-183.

71Jestphal, F. 1961. Zur Systematik der deutschen und englischen Lias Krokodilier. Neues Jahrbuch, 716 für Geologie und Paläontologie. Abhandlungen 113:207-218.

7Wharton, D. S. 2000. An enlarged endocranial venous system in Steneosaurus pictaviensis 718 (Crocodylia: Thalattosuchia) from the Upper Jurassic of Les Lourdines, France. Comptes

719 Rendus de l'Académie des Sciences, Series IIA, Earth and Planetary Science 331 :221-226.

720intrich, T., S. Hayashi, A. Houssaye, Y. Nakajima, and P. M. Sander. 2017. A Triassic

721 plesiosaurian skeleton and bone histology inform on evolution of a unique body plan. Science 722 advances 3:doi:10.1126/sciadv.1701144

723itmer, L. M., and R. C. Ridgely. 2009. New insights into the brain, braincase, and ear region of 724 tyrannosaurs (Dinosauria, Theropoda), with implications for sensory organization and 725 behavior. The Anatomical Record 292:1266-1296.

7201tmer, L. M., R. C. Ridgely, D. L. Dufeau, and M. C. Semones. 2008. Using CT to peer into the 727 past: 3D visualization of the brain and ear regions of birds, crocodiles, and nonavian 728 dinosaurs; pp. 67-88 in H. Endo, and R. Frey (eds), Anatomical imaging: towards a new 729 morphology. Tokyo, Japan, Springer.

7310yneken, J. 2003. The external morphology, musculoskeletal system, and neuro-anatomy of sea 731 turtles; pp. 39-77 in P. L. Lutz, J. A. Musick, and J. Wyneken (eds), The biology of sea 732 turtles. Vol. 2, CRC Press, London.

736yneken, J. 2007. Reptilian neurology: anatomy and function. Veterinary Clinics of North 734 America: Exotic Animal Practice 10:837-853.

735ubmitted May 17, 2018; accepted Month DD, YYYY 


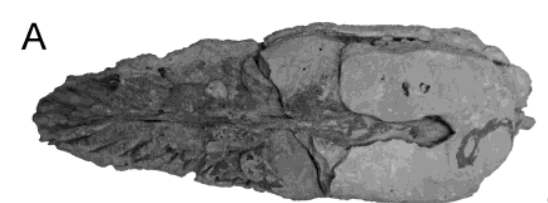

B

738

\section{9}

740

741

742

743

744

745

746

747

748

749

750

751

752

753

754

755

756

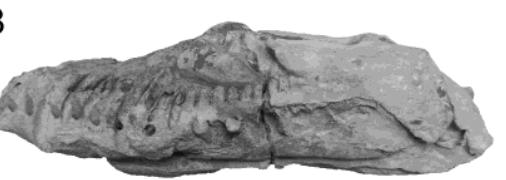

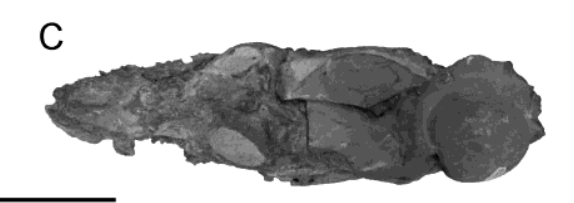
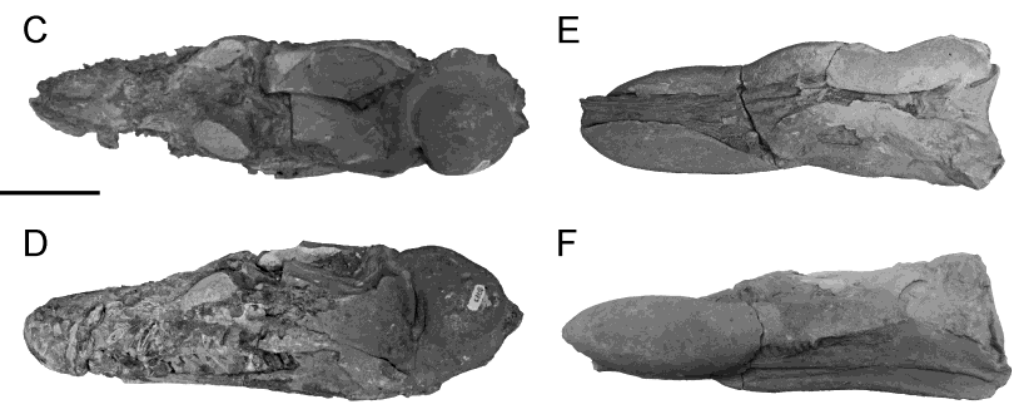

F

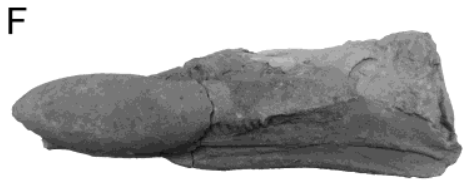

FIGURE 1. Photographs of the Libonectes morgani specimens D1-8213 (A, B) and SMNS 81783 (C, D); and of the undetermined polycotylid MNHN F-GOU14 (E, F), all from the lower Turonian of Goulmima (Morocco) in dorsal (up) and left lateral (down) views. Scale bar equals $10 \mathrm{~mm}$. [planned for page width] bar equals $10 \mathrm{~mm}$. [planned for page width]

FIGURE 2. Individual slice data (A-I) through the cranium of Libonectes morgani (D1-8213).

Positions of the transverse sections are shown in dorsal cranial surface model. Images in A-I not to scale. Abbreviations: bo, basioccipital; ect, ectopterygoid; ep, epipterygoid; eo, exoccipital-opisthotic; fr, frontal; p, parietal; pa/bs, parabasisphenoid; pal, palatin; pr, prootic; pt, pterygoid; so, supraoccipital. See Appendix 1 for cross sections from the two other specimens. [planned for page width] 


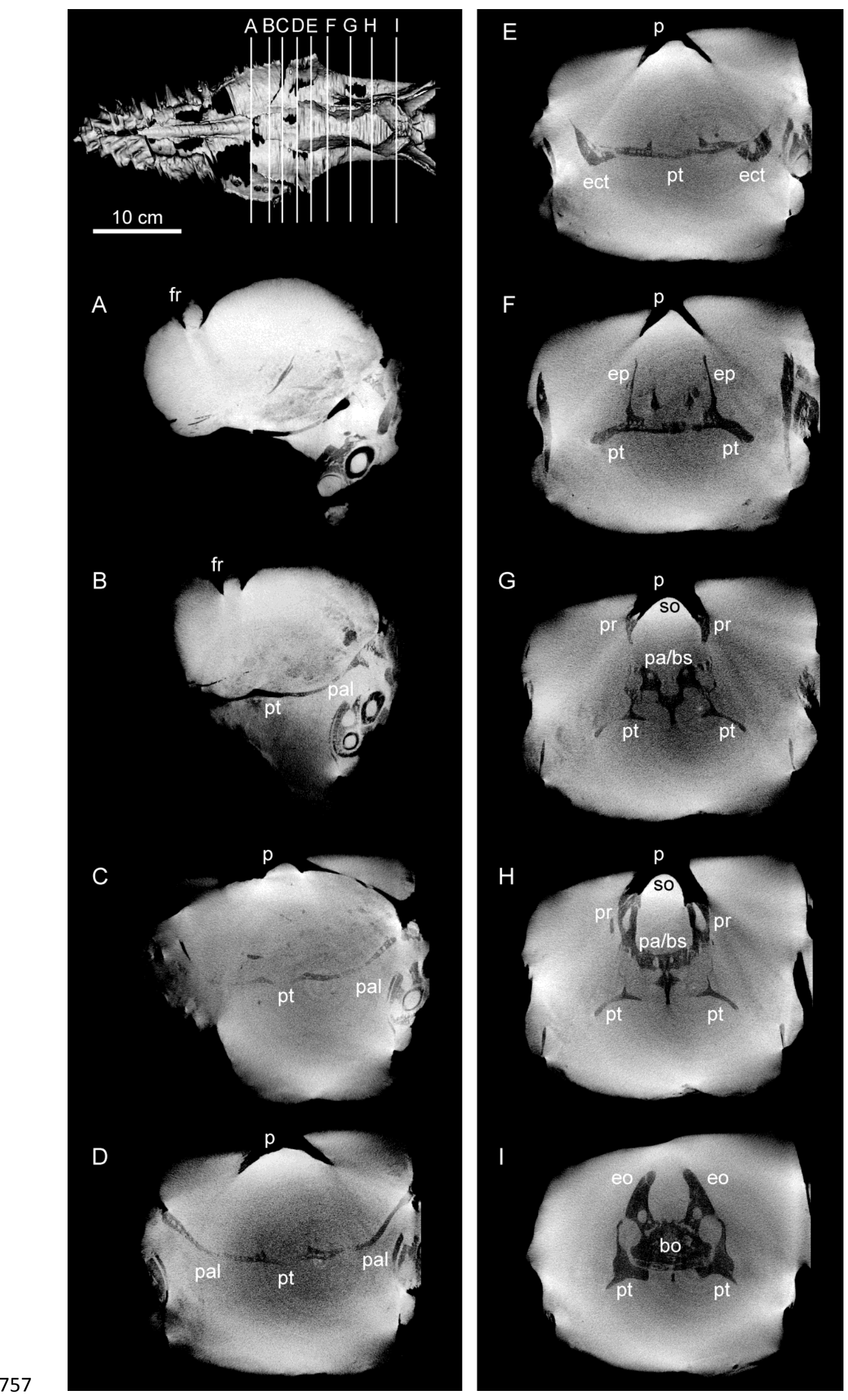


FIGURE 3. Virtual plesiosaurian endocasts of the Libonectes morgani specimens D1-8213

759

760

761

762

763

764

765

766

767

768

769

770

771

772

773

774

(A) and SMNS 81783 (B); and the undetermined Polycotylidae MNHN F-GOU14 (C) in dorsal (top) and left lateral (bottom) views. Abbreviations: cb, cerebellum; cer, cerebral hemispheres; ic, internal carotid; mo, medulla oblongata; ob, olfactory bulbs; ol, optic lobes; ot, olfactory tracts; po?, pineal organ; pit, pituitary bulb; V, trigeminal nerve; VI, abducens nerve; VII, facial nerve; IX, glossopharyngeal nerve; X-XI, vagus and accessory nerves; XII, hypoglossal nerves. Scale bars equal $20 \mathrm{~mm}$. The dotted-lines indicate the missing parts, the specimen $\mathrm{A}$ is used as a reference for other two specimens. [planned for $2 / 3$ of a whole page width]

(1) 
A

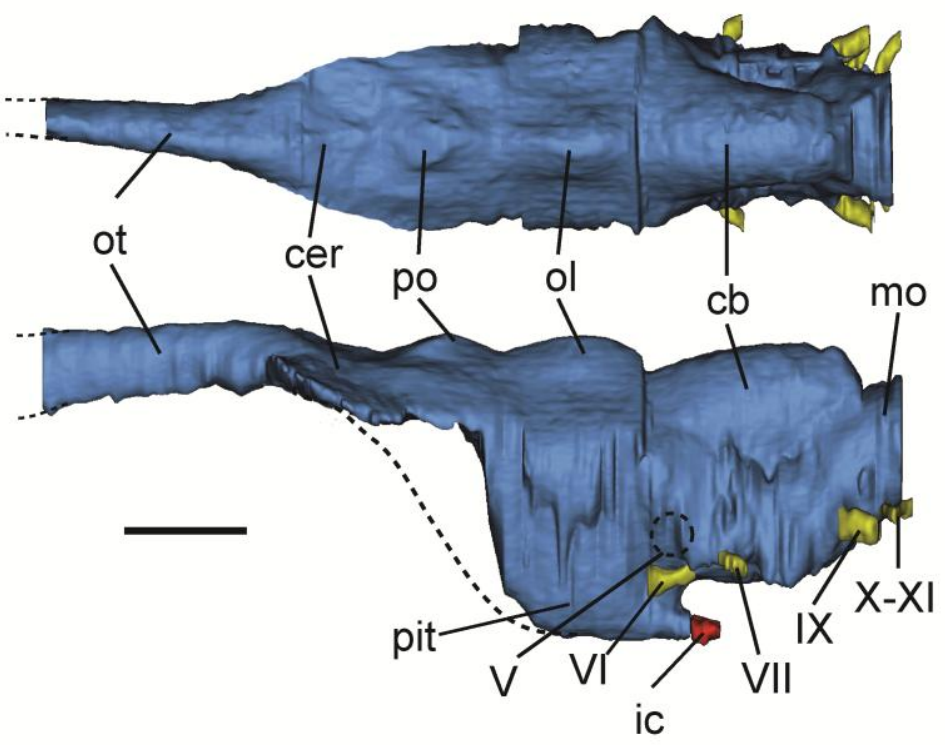

B

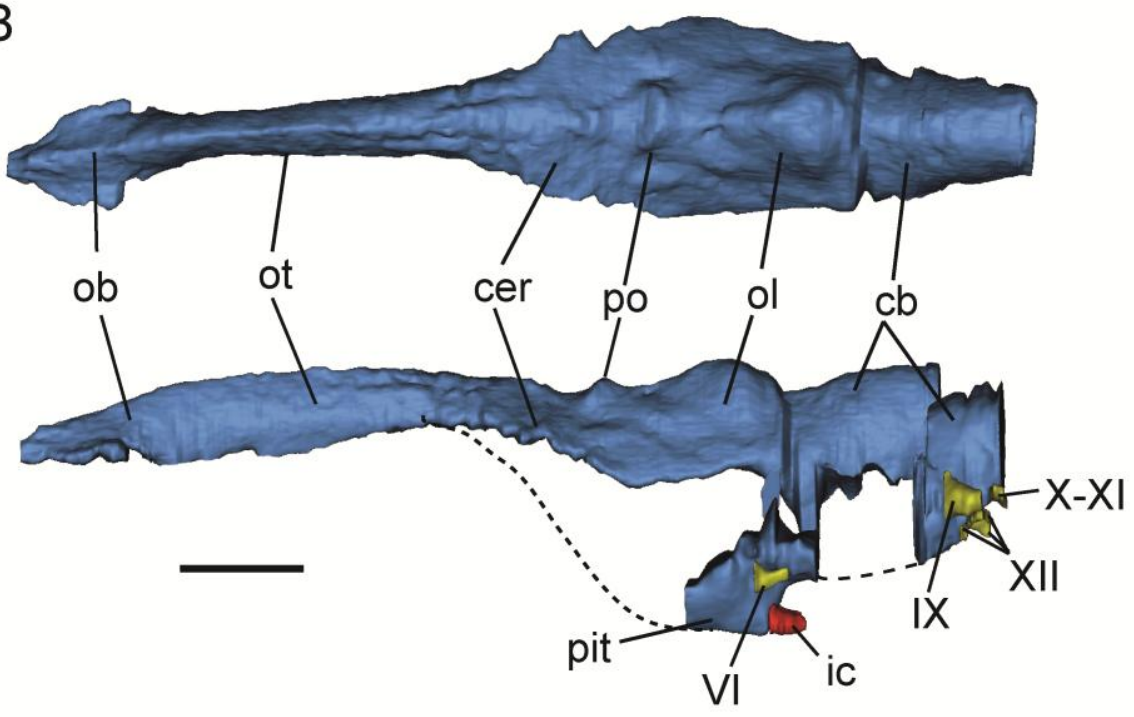

C

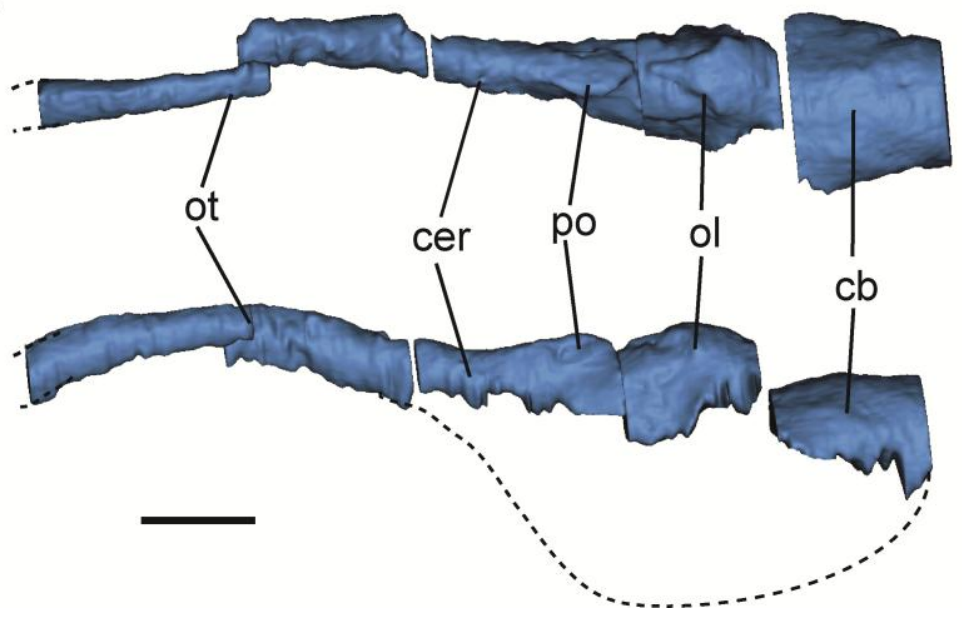


A

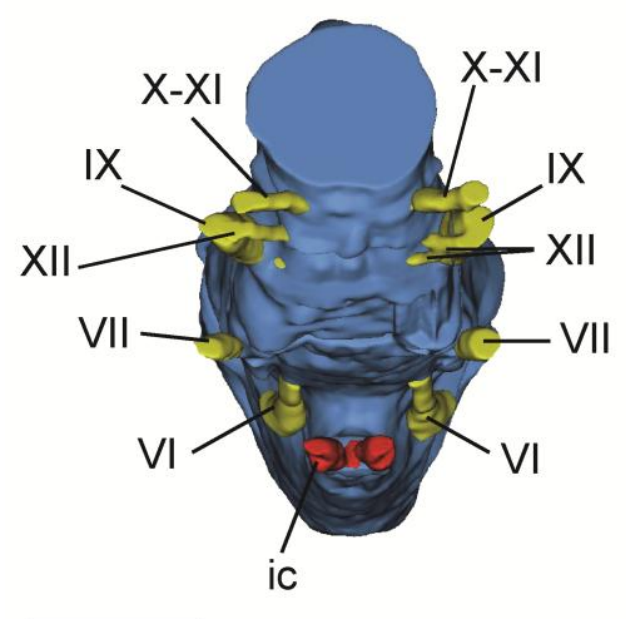

B

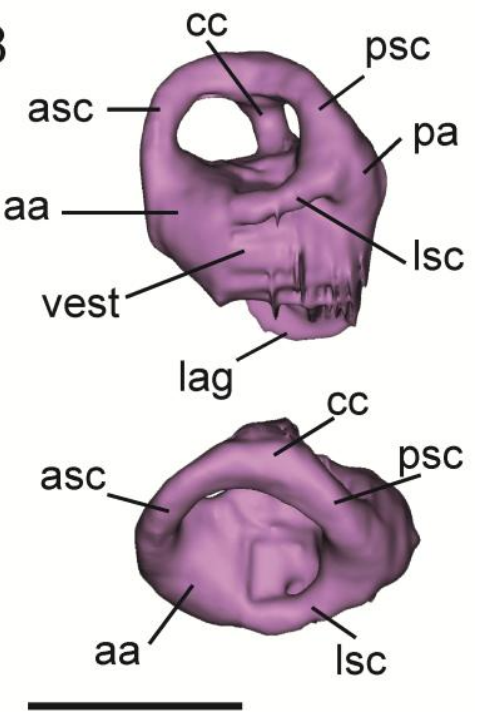

FIGURE 4. (A) Endocast of the more complete Libonectes morgani specimen D1-8213 in ventroposterior view showing the position of each cranial nerves. (B), Left endosseous labyrinth of D1-8213 in lateral (top) and dorsal (bottom) views. Abbreviations: aa, anterior ampulla; asc, anterior semicircular canal; cc, common crus; ic, internal carotid; lag, lagena; Isc, lateral semicircular canal; pa, posterior ampulla; psc, posterior semicircular canal; vest, vestibule; VI, abducens nerve; VII, facial nerve; IX, glossopharyngeal nerve; X-XI, vagus and accessory nerves; XII, hypoglossal nerves. Scale bars equal $20 \mathrm{~mm}$. [planned for $2 / 3$ of a whole page width] 